\title{
The Influence of Lean Practices and Leadership on Business Excellence: Malaysian E\&E Manufacturing Companies
}

\author{
OON FOK-YEW ${ }^{1}$, NOR AZIATI ABDUL HAMID ${ }^{2}$ \\ Faculty of Technology Management and Business, UNIVERSITI TUN HUSSEIN ONN MALAYSIA, MALAYSIA. \\ ${ }^{1} \mathrm{E}$-mail: oonfokyew@gmail.com \\ 2E-mail: aziati@uthm.edu.my
}

\begin{abstract}
The objectives of this study are to adopt the well-known business excellence model (BEM), Baldrige excellence framework 2019-2020 criteria and examine in Malaysian Electrical and Electronics (E\&E) manufacturing companies. We have identified those elements in BEM like leadership, customers, measurement, analysis, knowledge management (MAKM), strategy, and operations that influence on business results. This study also aims to assess the Lean practices influence on the operations and results of business excellence (BE). The theoretical framework is guided by BEM and Leadership theory. A stratified random sampling was employed to choose the sample from the four sub-sectors of E\&E industry. A total of 500 questionnaires was circulated in Peninsular Malaysia with return usable 156 questionnaire utilized for data analysis. The outcome from the structural analysis suggested that positive relationships between strategy, operations, and Lean practices on achievement of BE. The limitations from present study suggest a future research may focus on other industries, Industry 4.0 companies and also ascertain what are the leadership behaviours more favourable to achieve BE. The conclusions of this study extend the knowledge by assisting theory building efforts especially in the operations management domain and BE management. The practical implication is adoption of Baldrige excellence framework and Lean practices will enhance infrastructural decision in fields of business strategy such as human resource policies, best practices, benchmarking and quality management. This study contributes to the methodology perspective by covering both economic and non-economic performance measure metrics.
\end{abstract}

Keywords: Lean Practices, Leadership, Business Excellence, E\&E, BEM

JEL Classification: L 


\section{Introduction}

In today competitive and complexity of business environment, the adoption and importance of quality improvement programmes are growing day by day as to fulfil customers who are more concern about product quality (Shafiq, Labrador \& Hafeez, 2017). An extensive list of those initiatives has been detected in the literature comprising total quality management (TQM), advanced manufacturing technology (AMT), total preventive management (TPM), just in time (JIT), Six-Sigma, and Lean Manufacturing, business excellence (BE) and new era of industrialization like Industry 4.0. All these initiatives are to guide organizations on continuous improvement, innovation processes and system to achieve better performance like improve production efficiency, enhance quality of product and service render, and customer satisfaction fulfilment. Choosing among these novel concepts, present study is focus on integration of $B E$ and Lean practices to examine their influence on organisational performance in Electrical and Electronics (E\&E) industry within Malaysia.

BE highlights on achieving excellence in all aspects of an organization that contains strategy, customer focus, leadership, people, information management, and processes. Hence, pursuing greater business results is a final goal (Misron et al., 2017). The implementation of BE with key variables embedded assist as a tool to find out their weaknesses and strengths by an organization. European Foundation of Quality Management (EFQM) and Malcom Baldrige National Quality Award (MBNQA) models are the most commonly employed for self-assessment, quality awards and proven excellence models (Samuelsson \& Nilsson, 2002; Misron et al., 2017). In this study, we adopted the latest Baldrige excellence framework 2019-2020 to investigate the perceived performance gap in pursing BE by Malaysian E\&E organizations.

The Malaysian E\&E industry is facing substantial challenges in sustaining growth with rising competition from Taiwan, China, Singapore, Thailand, Vietnam and remaining countries in Asian. Therefore, Malaysia E\&E's organizations required to strengthen the available set of competencies and capabilities in order continuously growing in the market as compare to their competitors. Moreover, they urged taking a closer look at why BE is important in support long-term business (Gerenuk, 2015). In contrast, E\&E industry in Malaysia is confronting its major economic challenge which trapped between high innovation economies of the world and the cost-effective manufacturing economies of Vietnam and Myanmar (Winifred, 2016). Act as long mainstay of Malaysia exports, E\&E industry of Malaysia should continue to rise up the value-added chain and reach the level of competitiveness.

In Malaysia there were more than 4,100 organizations in adopted the Malaysia Business Excellence Framework (MBEF) (MPC, 2019). A recipient of Industry Excellence Award or locally known as Ameerah Kecemerlangan Industri (AKI) award will distinguish the recipients against other companies for implementing best practices and recording significant productivity achievements. The Ministry of International Trade and Industry (MITI) was introduced this AKI award since 1991 is to recognize excellent Malaysian companies and to promote continuous improvement in products and services offered. However, we have discovered extremely low participation rate of E\&E in the Industry Excellence Award in recent years which recorded one percent or lower if compared with total 2,235 E\&E companies that have been registered under Federation of Malaysia Manufacturers (FMM, 2018). The low participation rate may lead to current research to explore the gap of BE practices in E\&E organizations.

In the nutshell, the overall objectives of this research aiming to measure how well the Malaysian E\&E companies engaged with Lean practices and to describe Lean as the practices deployed and how it has significant positive influence on the BE of organizations. In addition, the leadership of organization drive to achieve better outcomes of BE through strategy, customers, MAKM, workforce and operations improvement.

\section{Problem Statement}

In 2018, the E\&E sector's contribution 5.4 percent share of gross domestic product (GDP) in Malaysia economy. The largest driver of exports in Malaysia, E\&E sector accounted almost RM373 
billion in exports in recent year 2019 and decrease compared to the previous year when value peaked at RM382 billion (DOSM, 2019). In the past two decades, E\&E sector exports decreased dramatically from year 2000 as high as $61.7 \%$ to $38.1 \%$ in recent year 2019. While facing challenges maintaining a largest share of Malaysia's export composition, the E\&E's companies have to fully utilized its resources effectively either in supply-chain or operations to secure sustainability of growth. Managers and executives in a company need to enhance themselves internal abilities to confront with company at strategies, changes and issues in pursuing excellence in their operations. In present study, the author willing to verify on what extend Lean practices can help organization to achieve superb performance and to find out how far the Leadership will drive E\&E company to achieve BE. By analysing large-scale data collected from Malaysia's E\&E companies, this work fills a gap in the literature.

In most manufacturing performance evaluation, the four common variables are used to measure the operational performance including quality, speed/time, cost and flexibility (Voss, 1995a; Kuruppuarachchi \& Perera, 2010; Wickramasinghe \& Wickramasinghe, 2017). In today, almost all four variables are still use to measure performance of manufacturing companies who focus on economic or financial measures of company performance (Bento \& Tontini, 2018; Sahoo \& Yadav, 2018). Conversely, still found limited research in the scope of non-economic performance (Shafiq, Lasrado \& Hafeez, 2017; Muogboh \& Salami, 2009). Simboli, Taddeo and Morgante (2014) concluded a gap still exist concurrently meet both economic and the non-economic objectives. The professional literature suggested that should include both economic and non-economic performance measures when managers design new performance measurement systems (Gosselin, 2005). On top of convention operational performance measures, the authors attempt to composite both economic (e.g. financial results and market share) and non-economic (e.g. product, process, people and customer results) adopted from latest Baldrige excellence framework to measure manufacturing company towards $\mathrm{BE}$ in present study.

Even through E\&E is a major manufacturing sector in the country, this sector had less than 10 companies been short listed in AKI 2018 Awards with a total of 40 participated companies. There will be less than one percent participation rate compared with a total of 2,135 companies of E\&E that registered under Federation of Malaysia Manufacturers (FMM, 2018). The low participation rate may due to either the organization being rejected during assessment stage by using MBEF assessment criteria, did not meet the AKI entry requirements, or maybe did not understand the benefits of $B E$ awards. Thus, it would be interesting to explore where is the greatest need for improvement in this study and perhaps can help E\&E companies to close this gap towards the achievement of BE.

Leadership is view as a core component for any firm, and excellent firms typically have good leadership. Kartika and Kanaloa (2017) defined leadership is the specific behaviour of setting required in the pursuit of excellence. In past studies, most leadership drawn from common leadership behaviour (Kanji, 2002) but the specific style or behaviour is essential to lead a continuous improvement initiative that have yet to be well-defined (Laureani \& Antony, 2017). In accordance with a literature search, limited research seems to have done on Baldrige's leadership setting and their effects upon BE in Malaysia manufacturing industry. Therefore, this study tends to discover how leadership from Baldrige system perspective affects achievement of BE. This paper is also to bring new perceptions into the debate on the leadership as key enabler BE in the Malaysia E\&E industry.

Past studies mostly focus on tools and techniques Quality Management (QM) or TQM that related to the overall organization performance. However, limited studies in using Lean tools to achieve BE (Price, 2018; Ghobakhloo \& Azar, 2018). Lean enablers continuous improvement in the manufacturing industries and helps the organization to enhance their performance through achieve operational excellence and quality (Ahmad \& Elhuni, 2014; Thomas et al., 2016; Sreedharan et al., 2017; Albliwi et al., 2014). Lean tools have become more dominant in operations and lead to increased performance. Many scholars that have identified Lean as improvement initiatives as important to deploy BE (Slack et al., 2013). However, limited discussions on the Lean implementation to achieve the BE in Malaysia context (Wahab et al., 2016). To enrich the holistic perspective, the authors feel there is a need to addon Lean practices to access the BE in Malaysia E\&E organizations. Within those studies, the number 
was limited to research with combination of Lean practices and BE elements to predict performance of organizations, particularly in manufacturing environment.

\section{Literature Review and Theoretical Framework}

\subsection{Business Excellence Models}

The Business Excellence Models (BEM) is claimed more comprehensive in nature compare to early TQM models. However, the greatest approaches to excellence can refer back to the origins of TQM of its excellence concept. Indeed, BE warrants full integration of improvement activities in an organization (Zdrilic \& Dulcic, 2016). They are numerous BE Models were established in providing a framework for BE. According to Kanji (2002), the most prominent business models are Deming Prize, MBNQA, EFQM, Kanji's Business Excellence Model (KBEM) and Balanced Scorecard (BSC). By focusing and comparison between MBNQA and EFQM which had led to at least 76 countries over the world developing a national BE awards based on the principles of both two awards (BPIR, 2020).

The MBNQA was developed in America which presented a significant step forward in achieving quality management in 1987. MBNQA was represented the initial defined TQM model on which the award was based on performance excellence. Following in 1991, EFQM model with the purpose to promote quality through Europe follow by their western counterparts. In the Western countries, formerly termed "Quality or TQM Models" being renovated as BEM in mid-1990 which resulted from a change in terminology from "quality" and "TQM" to business (organizational) excellence (Adebanjo, 2001). It was used by many authors in quality management literature (Kanji, 2001). In short, BE is a development of TQM since it is constructed on the similar values. The recent released Baldrige excellence framework 2019-2020 has seven dimensions of excellence namely Leadership, Customers, Strategy, Operations, Workforce, MAKM and Results. The seven criteria will assist the Malaysian companies to plan, execute and measure scopes that have linked to the dimensions of excellence. Thus, the BEM will be able to guide the present study in which the Lean is improvement tools, and leadership use to drive the manufacturing companies to achieve BE.

\subsection{Leadership Theory}

Leadership is defined as motivating, influencing or empowering others to contribute to the achievement of organization or task which of they are followers (House, Javidan, \& Dorfman, 2001). This common definition is based on global leadership study with the data collected from 54 leadership experts in 38 countries. Analysis of global leader study in the first round has generated 21 leadership scales and then transform into six superordinate leadership styles. The six leadership styles included charismatic style, humane style, autonomous style, team-oriented style, participative style, and selfprotective style (Javidan \& Dastmalchian, 2009). Each style is seen make a contribution to remarkable leadership in some culture or all culture. This Global Leadership and Organizational Behaviour Effectiveness (GLOBE) research concluded by emphasizing the significance of the study is a need of emerging a global viewpoint for leader-managers with the assumption that all leader-managers have to develop a global mind-set or a global perspective.

According to Laureani \& Antony (2019) and Yukl (2006), leadership could be classified into the five leadership theories that derived from most of the literature review. First is behavioural perspective, it classifies leaders' behaviours into two clusters either task-oriented or people-oriented. Second is contingency perspective, it believes powerful leaders will accommodate their leadership styles to the situation. Third is competency perspective, it attempts to find the personality traits of effective leaders. Fourth is transformational perspective, it declares that leaders set and convey a vision. Fifth is implicit leadership perspective, it conveys the significant of leadership is inflated and consider human need for control.

In addition to executive board, it is important that everyone should agree leaders exist everywhere in organization, also regardless which theory one wants to follow through (McShane \& Von Glinow, 2008). Successful leaders are considered as those who are flexibly and accurately adapt their behaviour 
to various situational constraint on the choice of a leadership style (Miner, 2005). A good leader must be flexible and adjust the plan to change circumstances in today competitive business environment. Furthermore, the area of quality management often been emphasised the importance of leadership (Laureani \& Antony, 2017). Despite to such thought, little research has been championed concerning the theoretical mechanisms by that Lean, leadership, and BE are linked. This study provides an attention on similar issues with the expectation of inspiring more literature review efforts. Attention is focus on the mutual influence of Lean practices and Leadership based construct on the $B E$ dimensions.

\subsection{Business Excellence Evolution}

In the mid-1990s, formally named "Quality or TQM Models" was renowned as "Business Excellence (BE) Models" (Adebanjo, 2001). Kanji (2001) described that BE has similar meaning as TQM and TQM evolution since it built on the equal values. Lu, Betts and Croom (2011) suggested that the drive to BE in practice as in including theory is generated from the continued expansion of TQM. It is definitive departure from TQM gradually. On the other hand, Sony (2019) reported that TQM was a very broadly used technique in the 1980s and 1990s. However, the influence of it was reduced due to Lean and Six Sigma in the late 1990s.

The search for organizational excellence has caused in diverse paradigms and conceptualizations (Hermel, 1997), and a worldwide viewpoint is emerging through the combination of several models of quality in excellence (McDonald, Zairi \& Idris, 2002). In 1951, the Deming Prize was the first globally recognized BEM which created by JUSE (Union of Japanese Scientists and Engineers, 2010). Next was the introduction of the CAE Quality Award in 1984 in Canada (National Quality Institute, 2007). Then in 1987, the US Congress created the MBNQA. Later, follow by the European Excellence Award in 1991 (formally known as European Quality Award), it was created in accordance to European Foundation for Quality Management (EFQM) model (EFQM, 1999). Likewise, in Asia, several counties have established their home countries quality awards in 1990s by referring to MBNQA and EFQM model. Those Asian counties included Malaysia in 1992, India in 1994, Japan and Singapore in 1995, Philippines in1997, and Thailand in 2001.

Metaxas and Koulouriotis (2017) investigated the evolution timeline, changes and documentation of BE Models from the year 1990 to 2016. They discovered articles regarding manufacturing sector were firstly introduced from year 1990 to 1995. After Year 2002, the research was a wide interest in other industries covered SMEs, education, services, hospitality, retail, public sector, transport, food, trade, pharmaceutical, constructions, telecommunications and law. However, the most of the current research frameworks have excluded criteria to quantity the ability of being agile and majority of the studies still used traditional approaches for BE Models. Therefore, it is fully recommended that researchers to keep posted or develop their frameworks timely since this will provide the chances to the firms to be best placed in the evolving trends. Thus, present study is to bring new insights into the discussion on the Lean and Leadership as key enablers BE in the Malaysia E\&E industry.

\subsubsection{Results of Company Performance}

Ferdowsian (2016) highlighted that existing BE, National Quality Awards and TQM approaches is start with leadership and end with results. In general, BE models granted a structured and systematic method toward enablers of total quality along with the business results obtained. Hence, this research aims to fill up the gaps by including both economic (e.g. market and financial results) and non-economic (e.g. customer-focused, workforce-focused, product \& process, and leadership \& governance results) (Staughton \& Johnston, 2005; Ghobakhloo \& Azar, 2018; Bento \& Tontini, 2018; Alsmadi, Almani \& Jerisat, 2012; Su, Baird \& Blair, 2009; Jurburg et al., 2017; NIST, 2019) performance measures that have a significant effect on long-term sustainability of an organization and sustainable excellence is a longterm process (Gerenuk, 2015). This study also considers wide perspectives by giving empirical evidence on the impact of drivers in manufacturing excellence are not limit to operational performance. 
BE can be defined as excellence in business practices, strategies, and stakeholder-related achievement results that have been assessed and validated by utilized proven BEM (Adebanjo \& Mann, 2008). Eventually, BE represents best practices in managing organizations by deliver of constantly improving value to stakeholders and customers, supporting to organizational sustainability. Results of firm performance lie in improvement and performance of organization in all important areas included leadership and governance results, financial, market and strategy results, product and process results, work force results, and customer results. Moreover, Leadership excellence have a positive relationship with employee outcomes, organization outcomes and customer results (Oakland \& Tanner, 2008). Thus, we are predicting BE results is not limited to relation between leadership and BE results but each element of Baldrige excellence framework in present study.

\subsubsection{Leadership}

Giving to past studies in BE, leadership as a key enabler field for a research across different industries. It is anticipated that the Leadership style and the employee involvement in the firm will express some consistent themes as a global model, the EFQM Excellence Model (Oakland \& Tanner, 2008). They found there was a positive linkage between the leadership excellence level and performance. The findings also portrayed that leadership excellence have a positive effect on three main stakeholder groups included organization outcomes, employee outcomes and customer results but not for the society stakeholders. An effective leader behaviour and altitude have been considered and showed as one of the main drivers towards enhancing organisational achievement and attaining total quality (Samawi et al., 2018; Juran, 1986). Rao (2016) quoted that firms should discover the role of soft leadership in attaining organisational excellence and effectiveness. Before implementation a future vision, the leader has to translate into strategic planning, communicate, embrace change, develop plans and establish an operating model in their organization. Soft leadership skill is the essential to translate vision into reality.

Brown (2013) described that top management team are often develop strategic plans and its effectiveness depends on the extent of engagement throughout the organization. For example, once strategy has been developed, senior management need to communicate and engage employees with that strategy. Moreover, leader must educate people and work with them to align their behaviours and thinking with the redesigned management approaches, systems, and processes to pursue significant changes. Simultaneously, the leader must recognize the requirements and expectations first of their internal customers (employees). Because employees will enhance processes and dedicate a highest-quality service to the external customers once they are satisfied. Southwest Airlines attributes its continued success by emphasis on employee satisfaction more than their customers. Hence, employees involve to set numerous of the operational procedures and make the company profitable (Vora, 2013). Hence, we hypothesize that good leadership would drive performances as specified in the following hypotheses:
$H_{1 a}$ : Leadership has causal positive effect on Strategy.
$H_{1 b}$ : Leadership has causal positive effect on Customers.
$H_{1 c}$ : Leadership has causal positive effect on MAKM.
$H_{1 d}$ : Leadership has causal positive effect on Workforce.
$H_{1 e}$ : Leadership has causal positive effect on Operations.
$H_{1 f:}$ Leadership has causal positive effect on Results of company performance

\subsubsection{Strategy}

The strategic planning emphasis on the business planning, company strategy and the deployment of plans. The strategic planning also is one of the eight dimensions of Lean practices. Likewise, the organizations have to pay attention to fulfil customer needs and wants, and operational performance. The emphasis is operational performance excellence which should incorporate into entire business 
planning since its as key business strategic matters (Bento \& Tontini, 2018). Everyone in the organization should understands planning is long-term and align it with these long-term goals. In addition, there should no major change in organization planning for every problem come across.

Krumwiede and Charles (2006) pointed out that top management involve in strategic planning is crucial which allows companies resource allocation and explain their urgencies for action. Business strategies essential fitting with the objectives and goals of organization in achieving high performance and improve competitive advantage (Samawi et al., 2018). Zott and Amit (2008) claimed that strategy generally purposes at improving performance of organizational. Afthonidis and Tsiotras (2014) discovered that strategic plan benefits company to enhance its market place and observed it as proper approach for achieving BE. Similarly, Aladwan and Forrester (2016) found that poor strategic planning, absence of employee empowerment, limited financial resources and weak integration are the key challenges that face by leaders when executing BE. Thus, we propose that strategy lead to the positive influence on BE.

$H_{2 a}$ : Strategy has causal positive effect on Customers.

$\mathrm{H}_{2 b}$ : Strategy has causal positive effect on Results of company performance.

\subsubsection{Customer}

Customer addresses on what extent the organization regulates current and emerging customer expectations and requirements, determines customer satisfaction and manages customer relationships effectively (Bento \& Tontini, 2018). Customer focus is a key concern for majority companies. Customer focused companies inform they control current and latest customer needs and wants, determines customer satisfaction and manages customer relationships effectively (Bento \& Tontini, 2018). Sharma and Kodali (2008) explained that organizations procedure, actions and all tasks which targeted at customer satisfaction are driven towards achieving customer happiness. Misron et al. (2017) studied 100 manufacturers of halal certified food in Malaysia and found that customer focus and operational performance has connection. The researcher also suggested that company resources must be assigned to fulfil customer need or requirements.

Matondang et al. (2018) have affirmed that customer element influence performance of palm oil factory with the research conducted using BE framework criteria. In similar study, customer variable found has direct influence on performance of palm oil factory, followed by leadership, workforce, strategy, MAKM and operations variables. Hence, it will be interesting to investigate customer have causal positive effect on BE. The hypothesis proposes as follows:

$H_{3}$ : Customers has causal positive effect on Results of company performance.

\subsubsection{Measurement, Analysis and Knowledge Management (MAKM)}

Gloet and Samson (2017) examined the knowledge management and the deployment of BE models can contribute to performance of innovation. The methodology used is case studies in six companies of Australia service sector that had won BE awards. The finding is Australian Business Excellence Framework (ABEF) experienced knowledge management is practicing and contributing to innovation performance in the six service sector companies. The study results also indicated that values of the ABEF shaped knowledge management activities through nurturing continuous improvement that in turn encouraged a stronger focus on incremental rather than radical forms of innovation.

Masrom et. al. (2017) noted that BE emphasis on strengthening and developing the management process and systems of an organization in which further leads to the enhancement of performance, therefore, generating value for investors. BE focuses on achieving excellence in all aspects of a firm that comprises knowledge management element. Certainly, attaining superior business results is the final goal. MBNQA functioned to recognize firms that show outstanding performances. The Baldrige model that is the basis of US quality award now functions as a basis for quality awards in many countries comprising Malaysia. It is still concentrating on the enhancement of all components of the 
firm, which contains activities and tasks at any level. We hypothesize that effective MAKM would drive performances as stated in the following hypothesis:

$\mathrm{H}_{4}$ : MAKM have causal positive effect on Results of company performance.

\subsubsection{Workforce}

Bakotic and Rogosic (2017) suggested that workers are accepted as the most vital asset of today's firms by both academics and practitioners. Without workers a firm could not reach its objectives and survive. Furthermore, it seems impossible to accomplish BE at workplace without the involvement and engagement of each worker. Few studies have presented that worker participation has been often connected directly or indirectly (Bakotic \& Rogosic, 2017). For example, production employees have an immediate impact on operations issues because they work in shop floor directly handle raw materials, controlling machine for product testing, and use tools in assembly processes. In Baldrige criterion, workforce was defined as all people managed by the firm and engaged in completing the organization work, including volunteers, paid employees and, as appropriate (NIST, 2019).

As the global surveys show that there is a strong relationship between workforce engagement and workforce achievement and business success with every manufacturing organization is focusing their efforts on increasing the levels of workforce engagement (Antony, Arulraj \& Umamaheswari, 2018). Manufacturing organizations face tough competition in terms of technological changes, retention of employees, global competition and there is need for an appraisal on their employee engagement in workplace. On the other hand, work engagement is most generally conceptualized as workers' vigor toward, absorption in, and dedication to their work events (Matthews et al., 2014). Hence, high employees' involvement is more likely to contribute to their organization success. Given this, this research assumes that:

$H_{5 a}$ : Workforce has causal positive effect on Operations.

$H_{5 b}$ : Workforce has causal positive effect on Results of company performance.

\subsubsection{Operations}

In mature environment, operations are considered by repeatability activities that are regularly assessed for improvement. Such results that are important to the company's ongoing success are trending in the right direction and doing well relative to other relevant organizations or competitors (NIST, 2019). Stoughton and Johnston (2005) suggested that all-pervasive operational performance objectives are quality, cost, flexibility, speed, and dependability. They provide the main impetus for operations management techniques and tools, such as Just-In-Time, Kanbans, ERP, SPC, and all of which are emphasized on doing things better, faster, more cheaply, and more efficiently.

According to Law of focus, operations which focus on a limited set of objectives will have more success in achieving these objectives than a factory, or organisation with a wide range of goals (Brumme et al., 2015; Found et al., 2018). This law is an important factor in achieving excellence in operations in that it must be aimed at specified operational objectives and business goals. Furthermore, each company is required to describe how they manage their business operations when submitting an application and applying for the award. The Baldrige program examiners is evaluating these applications as a first step in determining the award winners each year. These facts lead us to propose that:

$H_{6}$ : Operations has causal positive effect on Results of company performance.

\subsubsection{Lean Practices}

The Lean approach introduces the concept of "waste" in manufacturing. "Waste" is referring to any activity conducted by an organization which does not generate value for the end customer but absorbs resources. This idea derives from the Ohno's analysis (Ohno, 1978) who used the word Muda for the first time representing non-value activities in the Toyota Production System (TPS). The seven most 
regular types of waste are classified into inventory, motion, transport, waiting, over production, overprocessing and defects have defined (Womack, Jones \& Roos, 1991). Rasa, Raiman and Ahmad (2015) examined 50 manufacturing companies and concluded there is positive correlation between Lean Production (LP) and four measurements of operational performance included quality, flexibility, cost and delivery. The approach often reduces the time between a customer and delivery. Generally, the basic benefits of Lean Production practices are better quality, reduce costs and shorter lead times (Singh \& Chauhan, 2013).

According to Sezen et al. (2012), Lean practices can be categorized in two different elements consist of internal operational and external (i.e. customer and supplier relationships) implementations (e.g. e.g. Pettersen, 2009). The early is comprised of merely the Lean practices of organization internal operational systems. The latter is Lean applications that go beyond the boundaries of the firm, and include suppliers and customers (Alsmadi et al., 2012). Bento and Tontini (2018) described that Lean practices can be classified into eight dimensions derived from the measures suggested in previous studies. The eight dimensions included people, strategic planning, problem solving, tools and processes, quality at source, supplier integration, continuous improvement and customer focus. In this logic, Lean practices define highlights mechanisms needed to realize better business performance.

Previous research has recognized a positive correlation between Lean operations and operational performance (Furlan, Vinelli \& Dal Pont, 2011; Prajogo et al., 2016; Bento \& Tontini, 2018; Chavez et al., 2013). Lean operations eliminate obvious wastes that consist of waste elimination, pull production, quality at the source, zero defects, streamlining processes and continuous improvement (Vinodh \& Joy, 2012). In contrast, Lean supply chain is allowed to perform collaboration with suppliers and customers such as real-time synchronization of unique customer winning value, product transfer, logistics delivery capabilities, demand priorities and vital marketplace information. In fact, the Lean Supplier Chain Management (SCM) practices and principles have been broadly discussed (Liu et al., 2013).

Thus, present study will examine the deployment of Lean practices in manufacturing sector. Lean will be categorized into two elements namely Lean supply chain and Lean operations. Lean operation contains of setup time reduction, pull production, continuous flow and cellular manufacturing (Sezen et al., 2012; Nawanir et al, 2018) whereby JIT delivery by suppliers, customer involvement, supplier feedback, supplier development and are Lean supply chain (Alsmadi et al., 2012; Nawanir et al., 2018). In the present study, we expect that companies with high Lean practices benefits from a superior performance.

$H_{7 a:}$ Lean practices has causal positive effect on Operations

$H_{7 b}$ : Lean practices has causal positive effect on Results of company performance.

In this present study, the performance indicators (operational, customer and workforce) that have been discussed may be utilized to quantify performance of company in achieving BE. Especially, the dependent variable of $\mathrm{BE}$ was operationalized by measuring operational performance, customer results and workforce results in present study. Besides, Lean and Leadership are important variables affecting the planning, customer, people and process dimensions and so the BE outcomes.

In this authors' view, BE is a way to foster continuous improvement and beyond efficiency in managing day-to-day manufacturing operations. In order to achieve this favourable position, a factual understanding of operational performance is needed. The main operations' manager or executive must be able to describe, measure with metrics, modify actions fitted with the strategy and objectives of operation, change and revise to the performance objectives and organization's process when channelling today's challenges or capitalizing on tomorrow's opportunities. 


\section{Hypotheses and Research Model}

\subsection{Research Framework and Theoretical Underpinnings}

Based on a synthesis of the literature, this researcher believes that Lean practices and leadership are probable significantly positive to the BE of the company merely in situations in which the strategic planning, customer focus, employee involvement and process improvement are engaged to the practices in the Lean and leadership efforts. Based on empirical review, this study established a theoretical framework that integrates the importance of Lean practices and Leadership dimension for $\mathrm{BE}$. The various elements discussed in literature review is expressed diagrammatically to depicted relationship as show by Figure 1 below.

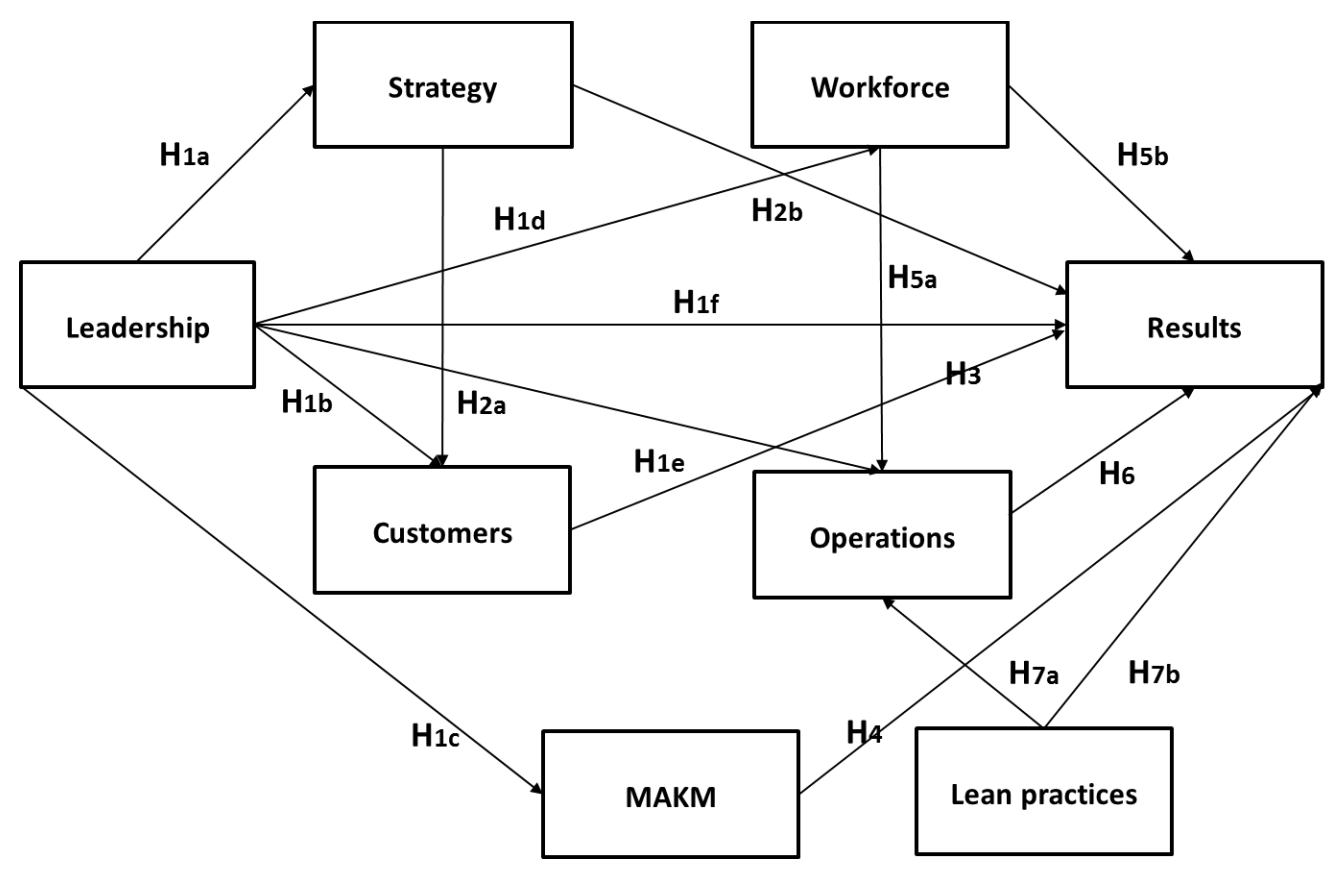

Figure 1. Relationships between Theoretical Framework and Research Hypotheses

In this study, various models and theories were examined in the discussion of BE. They include the Business Excellence Models (BEM) and Leadership theory. This study will review them because the two are relevant to the research topic.

\subsection{Research Hypothesis}

The current study is to examine the relationship between Lean practices, leadership and BE. Hence, the study aims to address below research hypothesis shown in Table 1 below.

Table 1: Summary of Research Hypotheses

\begin{tabular}{|c|l|}
\hline Hypothesis & \multicolumn{1}{c|}{ Statement } \\
\hline $\mathrm{H}_{1 \mathrm{a}}$ & Leadership has causal positive effect on Strategy. \\
\hline $\mathrm{H}_{1 \mathrm{~b}}$ & Leadership has causal positive effect on Customers. \\
\hline $\mathrm{H}_{1 \mathrm{c}}$ & Leadership has causal positive effect on MAKM. \\
\hline $\mathrm{H}_{1 \mathrm{~d}}$ & Leadership has causal positive effect on Workforce. \\
\hline $\mathrm{H}_{1 \mathrm{e}}$ & Leadership has causal positive effect on Operations. \\
\hline $\mathrm{H}_{1 \mathrm{f}}$ & Leadership has causal positive effect on Results of company performance. \\
\hline $\mathrm{H}_{2 \mathrm{a}}$ & Strategy has causal positive effect on Customers. \\
\hline
\end{tabular}




\begin{tabular}{|l|l|}
\hline $\mathrm{H}_{2 b}$ & Strategy has causal positive effect on Results of company performance. \\
\hline $\mathrm{H}_{3}$ & Customers has causal positive effect on Results of company performance. \\
\hline $\mathrm{H}_{4}$ & MAKM have causal positive effect on Results of company performance. \\
\hline $\mathrm{H}_{5 \mathrm{a}}$ & Workforce has causal positive effect on Operations. \\
\hline $\mathrm{H}_{5 \mathrm{~b}}$ & Workforce has causal positive effect on Results of company performance. \\
\hline $\mathrm{H}_{6}$ & Operations has causal positive effect on Results of company performance. \\
\hline $\mathrm{H}_{7 a}$ & Lean practices has causal positive effect on Operations. \\
\hline $\mathrm{H}_{7 b}$ & Lean practices has causal positive effect on Results of company performance. \\
\hline
\end{tabular}

\section{Research Methodology}

In line with present study, quantitative research approach utilizes a survey method. A set of questions will be developed. A few manufacturers will be chosen to participate in pilot study in present research. Once data collection task completed, preliminary test to be carried out to confirm the interrater agreement, response rate, validity and reliability of the study construct. Then reliability analysis and factor analysis were carried out to assess the reliability and validity of the dependent variable, independent variables and the outcomes. The data analysis tools included Microsoft Excel, Statistical Package for Social Science (SPSS) and Partial Least Squares (PLS) will be utilized to analyse the data collected from the survey. The author will use SPSS for data screening and then test for common method variance to check common bias. Next is to use PLS approach for outer and inner model measurement. PLS analysis was used in present study because of the complex nature of the model and assessing the suggested framework.

\subsection{Population and Sample Size}

Since the study is about BE in Malaysian E\&E industry, it is appropriate that managers involved in manufacturing operations are considered. In this context, samples of the population are selected from the Federation of Malaysian Manufacturers Industry Directory Edition 49th of Malaysian Manufacturers (FMM, 2018) which is total of 2135 companies. The Malaysian E\&E industry can be categorized into four sub-sectors namely electronic components, industrial electronics, consumer electronics, and electrical products. In order to get each sector has proportion to the population, the researcher will use stratified random sampling by divides a population into four sub-sectors that derived from E\&E Industry. The target respondents are from managerial level which identified as responsible in running continuous improvement $(\mathrm{Cl})$ activities. The respondents may include Lean Manager, Lean Coordinator/Specialist, Business/Operational Excellence Manager, Cl Manager/Coach, Senior Executive who involve in $\mathrm{Cl}$ programs and company's Lean consultant.

The sample size of respondent chosen for this study is determined by Krejcie \& Morgan (1970). In addition, the sample size of this study compiled with the rule of thumb by Roscoe (1975) who suggested that for most research sample size bigger than thirty and less than five hundred are appropriate. The sample size according to the Krejcje \& Morgan Chart is 325 . Because the total registered company is 2135 and in between the range of 2000 to 2200 population. By studying the samples, the researcher was able to illustrate the conclusions that can be generalized to the population of interest.

\subsection{Instrument Development and Measurement}

A survey is a research approach in which data is collected from a sample of population through questionnaire. Structured questionnaires are widely used in field research, in experiments and other data collection activities because they are crucial to and most directly related with survey research (Babbie, 2005). In line with present study, a set of questions was developed. The questionnaire contains of four sections. Section A and Section B of the questionnaire is to ascertain the link between 
constructs. In Section C, it will also ask questions concerning the dependent variable effect the outcomes or results. Section D seeks information relation to participating companies' background information, where Section E solicits information regarding respondents' background including demographical information. Table 2 summarized the survey instrument construct for this study.

Table 2: Survey Instrument Construct

\begin{tabular}{|c|c|c|c|}
\hline Section & Title & Number of Items & Authors / Sources \\
\hline \multirow[t]{3}{*}{ A } & \multicolumn{3}{|c|}{ Measures of Independent Variables } \\
\hline & Leadership & 11 & $\begin{array}{l}\text { Baldrige assessment } \\
\text { criteria (2019) }\end{array}$ \\
\hline & Lean Practices & 31 & $\begin{array}{c}\text { Nawanir et al. (2018); } \\
\text { Wickramasinghe \& } \\
\text { Wickramasinghe (2017); } \\
\text { van Assen (2018); Vinodh } \\
\text { \& Joy (2012; Sezen et al. } \\
\text { (2012); Alsmadi et al. } \\
\text { (2012); Shah \& Ward } \\
\text { (2007); Souza Farias et al. } \\
\text { (2019); Abolhassani et al. } \\
\text { (2016). Poksinska \& } \\
\text { Swartling (2018) }\end{array}$ \\
\hline \multirow[t]{6}{*}{$\mathrm{B}$} & \multicolumn{3}{|c|}{ Measures of Dependent Variables } \\
\hline & Strategy & 13 & \multirow{5}{*}{$\begin{array}{l}\text { Baldrige assessment } \\
\text { criteria (2019) }\end{array}$} \\
\hline & Customers & 10 & \\
\hline & Measurement, Analysis, and knowledge management & 11 & \\
\hline & Workforce & 13 & \\
\hline & Operations & 12 & \\
\hline \multirow[t]{6}{*}{$\mathrm{C}$} & \multicolumn{3}{|c|}{ Measures of Outcomes } \\
\hline & Product and Process Results & 4 & \multirow{5}{*}{$\begin{array}{l}\text { Baldrige assessment } \\
\text { criteria (2019) }\end{array}$} \\
\hline & Customer Results & 2 & \\
\hline & Workforce Results & 4 & \\
\hline & Leadership and Governance Results & 5 & \\
\hline & Financial, Market and Strategy Results & 4 & \\
\hline $\mathrm{D}$ & $\begin{array}{l}\text { Company Information (company sub-sector, numbers } \\
\text { of employees, numbers of years of operation, annual } \\
\text { sales turnover, and type of ownership). }\end{array}$ & 5 & \\
\hline$E$ & $\begin{array}{l}\text { Demographic Characteristics (gender, ethnic group, } \\
\text { age, educational, employment, designation, and } \\
\text { company name). }\end{array}$ & 7 & \\
\hline
\end{tabular}

\subsection{Data Analysis}

The data analysis tools such as Microsoft Excel, Statistical Package for Social Science (SPSS) and Partial Least Squares (PLS)-Structural Equation Modelling (SEM) technique will be used to process the data obtained from this survey. A total of 159 respondents companies returned their questionnaires and usable data is 156 or recorded 31.2\%. as presented in Table 3.

Table 3: Analysis of Usable Data

\begin{tabular}{|c|c|c|}
\hline & No & $\%$ \\
\hline Total number of questionnaires distributed & 500 & 100 \\
\hline Non response & 344 & 68.80 \\
\hline Total usable questionnaires & 156 & 31.20 \\
\hline
\end{tabular}




\subsubsection{Respondent's Profile}

\subsubsection{Profile of the Respondent Companies}

Most manufacturing companies in the electrical and E\&E industry that answered to the survey were in the electronic component sector. As presented in Table 4, they comprised 46.0 per cent of the number of respondents, followed by those in electrical products sector (22.0 per cent), industrial electronics sector (17.3 per cent) and consumer electronics sector (14.7 per cent).

Table 4: Respondents in E\&E Sub-sector

\begin{tabular}{|c|c|c|c|c|c|}
\hline \multicolumn{2}{|c|}{} & Frequency & Percent & Valid Percent & Cumulative Percent \\
\hline \multirow{3}{*}{ Valid } & Electronic components & 69 & 46.0 & 46.4 & 46.0 \\
\cline { 2 - 6 } & Consumer electronics & 22 & 14.7 & 14.7 & 60.7 \\
\cline { 2 - 6 } & Industrial electronics & 26 & 17.3 & 17.3 & 78.0 \\
\cline { 2 - 6 } & Electrical products & 33 & 22.0 & 22.0 & 100.0 \\
\cline { 2 - 6 } & Total & 150 & 100.0 & 100.0 & \\
\hline
\end{tabular}

\subsubsection{Profile of the Respondent}

A tabulation profiles of the respondents is shown in Table 5 for ease of understanding. In relationship to gender, 70.7 per cent of the respondents were male and 29.3 per cent were female. In terms of age, 44.0 per cent of the respondents were between 36 and 45 years old, 34.7 per cent were above 46 , and 21.3 per cent were between 18 and 35 . Most respondents ( 34.0 per cent) had less than 5 year's tenure of employment with their current companies. In contrast, 28.0 per cent of the respondents had more than 16 years of being attaching to their current companies. Of the remaining respondents 21.3 per cent had between 6 to 10 years and 16.7 per cent had between 11 to 15 years. By managerial groups, 42.7 per cent of questionnaires were answered by middle-level managers, 19.3 per cent by lower-level managers, 32.0 per cent by top-level managers and 6.0 per cent by a professional such as company's advisors and consultants. The results inferred that the most of the E\&E manufacturing organizations followed the requirements as mentioned in the cover letter send along with the questionnaire.

Table 5: Profile of the Respondents

\begin{tabular}{|c|c|c|c|}
\hline \multicolumn{2}{|c|}{ Characteristics } & Frequency $(N=121)$ & Per cent (Total 100\%) \\
\hline \multirow[t]{3}{*}{ Gender: } & Male & 106 & 70.7 \\
\hline & Female & 44 & 29.3 \\
\hline & Total & 150 & 100 \\
\hline \multirow[t]{4}{*}{ Age: } & Between 18 to 35 years & 32 & 21.3 \\
\hline & Between 36 to 45 years & 66 & 44.0 \\
\hline & Above 46 years & 52 & 34.7 \\
\hline & Total & 150 & 100 \\
\hline \multirow{5}{*}{$\begin{array}{c}\text { Number of years working } \\
\text { in this company: }\end{array}$} & Less than 5 years & 51 & 34.0 \\
\hline & Between 6 to 10 years & 32 & 21.3 \\
\hline & Between 11 to 15 years & 25 & 16.7 \\
\hline & More than 16 years & 42 & 28.0 \\
\hline & Total & 150 & 100 \\
\hline \multirow[t]{2}{*}{ Position held: } & Low-level Managers & 29 & 19.3 \\
\hline & Middle-level Managers & 64 & 42.7 \\
\hline
\end{tabular}




\begin{tabular}{|c|c|c|c|}
\hline \multirow{3}{*}{} & Top-level Managers & 48 & 32.0 \\
\cline { 2 - 4 } & Professional & 9 & 6.0 \\
\cline { 2 - 4 } & Total & 150 & 100 \\
\hline
\end{tabular}

\section{Finding and Results}

\subsection{Measurement Model}

Initially the measurement model was tested for validity and reliability. We used three measures namely Indicator loading, Composite Reliability (CR) and Average Variance Extracted (AVE) to examine validity and reliability of each constructs, following the approach suggested by Hulland (1999), Bagozzi and Yi (1988), and Hair et al. (2013). The first one to check is "Indicator Reliability" by looking at each indicator or outer loading value. Table 6 shown that all indicators loadings is higher than 0.7 (Hulland, 1999; Wong, 2013). Previous literature has proposed the use of "Composite Reliability" as a replacement for "Cronbach's alpha" is used to measure internal consistency reliability particularly in social science research since Cronbach's alpha tends to offer a conservative measurement in PLS-SEM (Wong, 2013). The values in Table 6 are shown to be larger than 0.6, so high levels of internal consistency reliability have been confirmed among all six reflective latent variables (Bagozzi and $\mathrm{Yi}$, 1988; Hair, Ringle \& Sarstedt, 2012). Each latent variable's AVE is evaluated as to check convergent validity. By referring to Table 6 , it is found that convergent validity is confirmed because all of the AVE values are larger than the acceptable threshold of 0.5 (Bagozzi \& Yi, 1988).

Table 6: Result of Reliability and Convergent Validity

\begin{tabular}{|c|c|c|c|c|c|c|}
\hline Group & Constructs & Item Label & Indicator Reliability (outer loading) & Judgement & CR & AVE \\
\hline \multirow{11}{*}{ 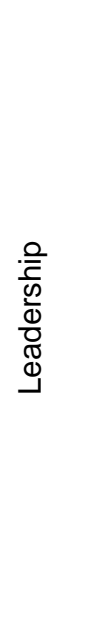 } & \multirow{5}{*}{ 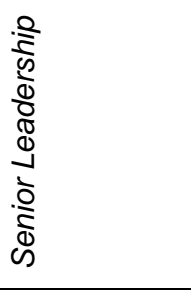 } & L_1 & 0.918 & Acceptable & 0.962 & 0.836 \\
\hline & & L_2 & 0.902 & Acceptable & & \\
\hline & & L_3 & 0.921 & Acceptable & & \\
\hline & & L_4 & 0.921 & Acceptable & & \\
\hline & & L_5 & 0.911 & Acceptable & & \\
\hline & \multirow{6}{*}{ 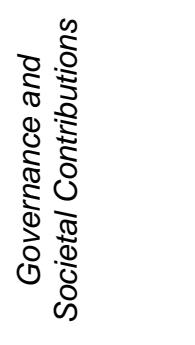 } & L_6 & 0.884 & Acceptable & 0.962 & 0.807 \\
\hline & & L_7 & 0.904 & Acceptable & & \\
\hline & & L_8 & 0.893 & Acceptable & & \\
\hline & & L_9 & 0.914 & Acceptable & & \\
\hline & & L_10 & 0.894 & Acceptable & & \\
\hline & & L_11 & 0.902 & Acceptable & & \\
\hline \multirow{10}{*}{ 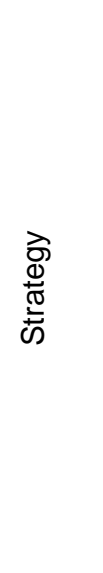 } & \multirow{6}{*}{ 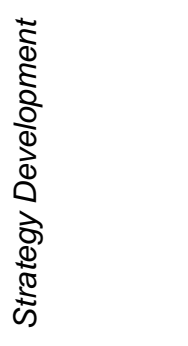 } & S_1 & 0.917 & Acceptable & 0.968 & 0.836 \\
\hline & & S_2 & 0.901 & Acceptable & & \\
\hline & & S_3 & 0.920 & Acceptable & & \\
\hline & & S_4 & 0.928 & Acceptable & & \\
\hline & & S_5 & 0.922 & Acceptable & & \\
\hline & & S_6 & 0.899 & Acceptable & & \\
\hline & \multirow{4}{*}{ 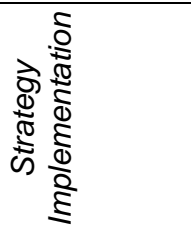 } & S_7 & 0.844 & Acceptable & 0.961 & 0.780 \\
\hline & & S_8 & 0.879 & Acceptable & & \\
\hline & & S_9 & 0.888 & Acceptable & & \\
\hline & & S_10 & 0.894 & Acceptable & & \\
\hline
\end{tabular}


The Influence of Lean Practices and Leadership on Business Excellence: Malaysian E\&E Manufacturing Companies

\begin{tabular}{|c|c|c|c|c|c|c|}
\hline & & S_11 & 0.899 & Acceptable & & \\
\hline & & S_12 & 0.886 & Acceptable & & \\
\hline & & S_13 & 0.887 & Acceptable & & \\
\hline \multirow{10}{*}{ 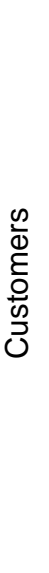 } & \multirow{4}{*}{ 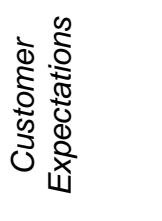 } & C_1 & 0.930 & Acceptable & 0.959 & 0.853 \\
\hline & & C_2 & 0,911 & Acceptable & & \\
\hline & & C_3 & 0.929 & Acceptable & & \\
\hline & & C_4 & 0.924 & Acceptable & & \\
\hline & \multirow{6}{*}{ 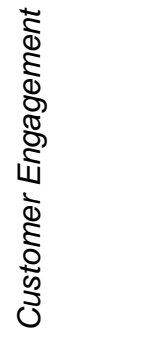 } & C_5 & 0.930 & Acceptable & 0.972 & 0.852 \\
\hline & & C_6 & 0.935 & Acceptable & & \\
\hline & & C_7 & 0.916 & Acceptable & & \\
\hline & & C_8 & 0.915 & Acceptable & & \\
\hline & & C_9 & 0.924 & Acceptable & & \\
\hline & & C_10 & 0.918 & Acceptable & & \\
\hline \multirow{11}{*}{$\underset{\sum}{\sum}$} & \multirow{6}{*}{ 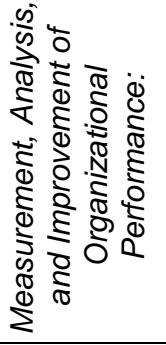 } & M_1 & 0.876 & Acceptable & 0.966 & 0.824 \\
\hline & & M_2 & 0.915 & Acceptable & & \\
\hline & & M_3 & 0.915 & Acceptable & & \\
\hline & & M_4 & 0.942 & Acceptable & & \\
\hline & & M_5 & 0.903 & Acceptable & & \\
\hline & & M_6 & 0.892 & Acceptable & & \\
\hline & \multirow{5}{*}{ 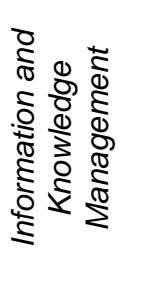 } & M_7 & 0.906 & Acceptable & 0.956 & 0.813 \\
\hline & & M_8 & 0.889 & Acceptable & & \\
\hline & & M_9 & 0.902 & Acceptable & & \\
\hline & & M_10 & 0.915 & Acceptable & & \\
\hline & & M_11 & 0.893 & Acceptable & & \\
\hline \multirow{13}{*}{ 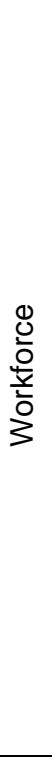 } & \multirow{6}{*}{ 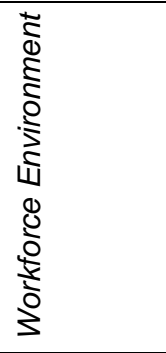 } & W_1 & 0.893 & Acceptable & 0.963 & 0.813 \\
\hline & & W_2 & 0.898 & Acceptable & & \\
\hline & & W_3 & 0.893 & Acceptable & & \\
\hline & & W_4 & 0.928 & Acceptable & & \\
\hline & & W_5 & 0.918 & Acceptable & & \\
\hline & & W_6 & 0.877 & Acceptable & & \\
\hline & \multirow{7}{*}{ 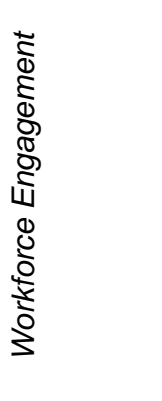 } & W_7 & 0.862 & Acceptable & 0.960 & 0.774 \\
\hline & & W_8 & 0.854 & Acceptable & & \\
\hline & & W_9 & 0.845 & Acceptable & & \\
\hline & & W_10 & 0.884 & Acceptable & & \\
\hline & & W_11 & 0.926 & Acceptable & & \\
\hline & & W_12 & 0.907 & Acceptable & & \\
\hline & & W_13 & 0.876 & Acceptable & & \\
\hline \multirow{4}{*}{ 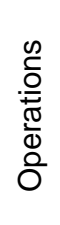 } & \multirow{4}{*}{$\begin{array}{l}0 \\
\mathbb{w} \\
\infty \\
8 \\
0 \\
0 \\
0 \\
x \\
5 \\
3\end{array}$} & O_1 & 0.870 & Acceptable & 0.968 & 0.791 \\
\hline & & O_2 & 0.881 & Acceptable & & \\
\hline & & O_3 & 0.860 & Acceptable & & \\
\hline & & O_4 & 0.894 & Acceptable & & \\
\hline
\end{tabular}




\begin{tabular}{|c|c|c|c|c|c|}
\hline & O_5 & 0.928 & Acceptable & & \\
\hline & O_6 & 0.915 & Acceptable & & \\
\hline & O_7 & 0.913 & Acceptable & & \\
\hline & O_8 & 0.849 & Acceptable & & \\
\hline \multirow{4}{*}{ 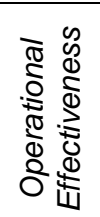 } & O_9 & 0.909 & Acceptable & 0.967 & 0.881 \\
\hline & O_10 & 0.949 & Acceptable & & \\
\hline & O_11 & 0.954 & Acceptable & & \\
\hline & O_12 & 0.941 & Acceptable & & \\
\hline
\end{tabular}

The step forward was to evaluate the discriminant validity. This is reported by low correlations between the measure of interest and the measures of other constructs. Table 7 presents that the square root of the AVE (diagonal values) of each latent variable value is greater than other correlations values among the latent variables towards sufficient discriminant validity (Fornell \& Larcker, 1981).

Several doubts of the Fornell and Larcker (1981) criteria proposed they do not reliably detect lack of discriminant validity in normal research situations (Henseler, Ringle, \& Sarstedt, 2015). Henseler et al. (2015) have proposed an alternative method to assess discriminant validity called heterotraitmonotrait (HTMT) ratio of correlations (Henseler et al., 2015). Discriminant validity was verified using this HTMT ratio and results are presented in Table 8 and Figure 2 demonstrated that total items fall lower compared with the threshold of 0.85 or HTMT.85. If the HTMT value is larger than 0.85 of HTMT.85 value then discriminant validity problem exists (Kline, 2011).

Table 7: Discriminant Validity using Fornell-Larcker Criterion

\begin{tabular}{|c|c|c|c|c|c|c|c|c|}
\hline & Customers & Leadership & LeanPractices & MAKM & Operations & Results & Strategy & Workforce \\
\hline Customers & 1 & & & & & & & \\
\hline Leadership & 0.406 & 1 & & & & & & \\
\hline LeanPractices & 0.343 & 0.275 & 1 & & & & & \\
\hline MAKM & 0.561 & 0.464 & 0.355 & 1 & & & & \\
\hline Operations & 0.420 & 0.378 & 0.345 & 0.558 & 1 & & & \\
\hline Results & 0.509 & 0.464 & 0.545 & 0.619 & 0.661 & 1 & & \\
\hline Strategy & 0.527 & 0.626 & 0.367 & 0.663 & 0.599 & 0.693 & 1 & \\
\hline Workforce & 0.434 & 0.365 & 0.226 & 0.487 & 0.547 & 0.498 & 0.551 & 1 \\
\hline
\end{tabular}

Note: Diagonals represent the square root of the AVE while the off-diagonals represent the correlations

Table 8: HTMT Criterion

\begin{tabular}{|c|c|c|c|c|c|c|c|c|}
\hline & Customers & Leadership & LeanPractices & MAKM & Operations & Results & Strategy & Workforce \\
\hline Customers & & & & & & & & \\
\hline Leadership & 0.406 & & & & & & & \\
\hline LeanPractices & 0.343 & 0.275 & & & & & & \\
\hline MAKM & 0.561 & 0.464 & 0.355 & & & & & \\
\hline Operations & 0.420 & 0.378 & 0.345 & 0.558 & & & & \\
\hline Results & 0.509 & 0.464 & 0.545 & 0.619 & 0.661 & & & \\
\hline Strategy & 0.527 & 0.626 & 0.367 & 0.663 & 0.599 & 0.693 & & \\
\hline Workforce & 0.434 & 0.365 & 0.226 & 0.487 & 0.547 & 0.498 & 0.551 & \\
\hline
\end{tabular}

Note: Shaded boxes are the standard reporting format for HTMT procedure 


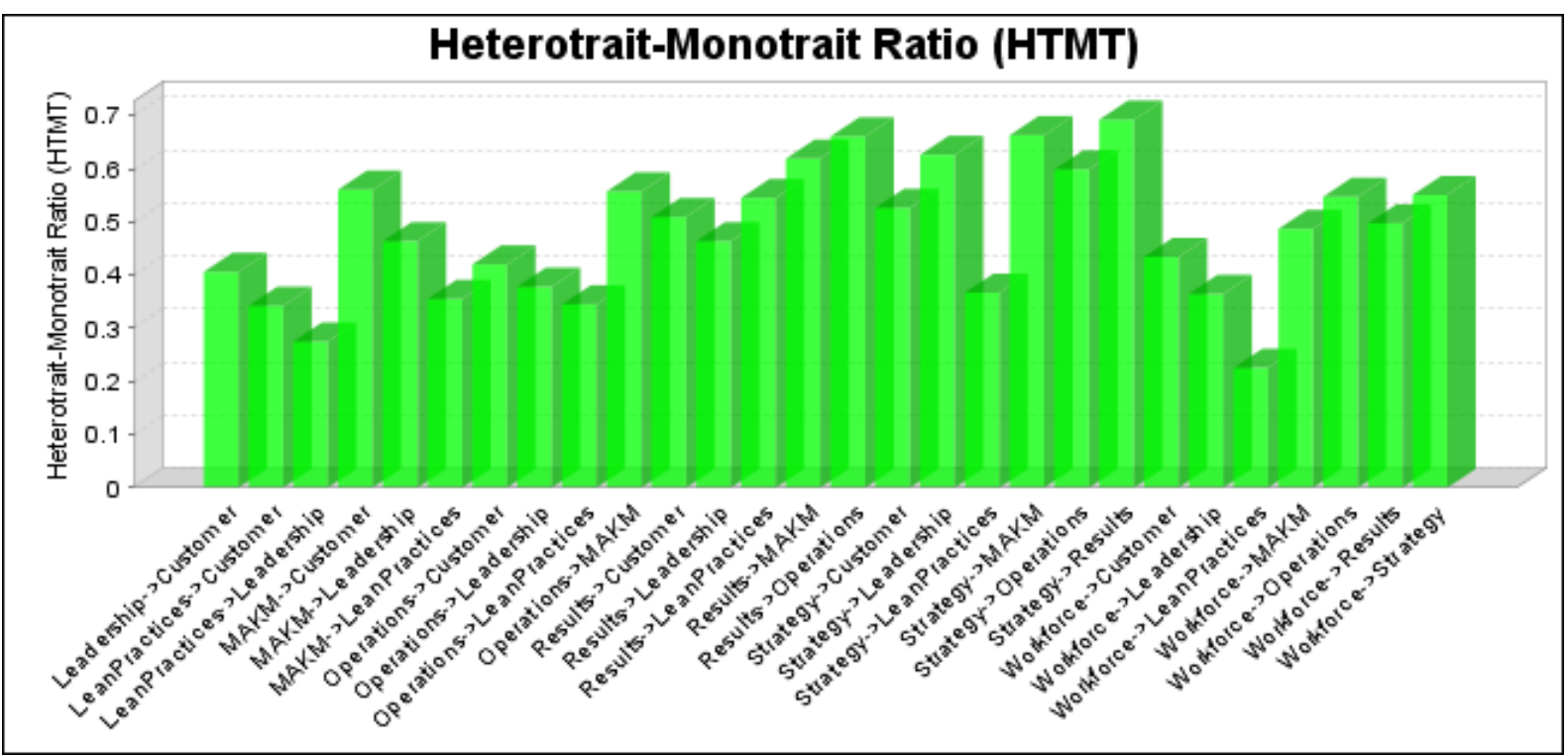

Figure 2: HTMT Ratio

\subsection{Assessment of Goodness-of-Fit (GoF)}

Hair et al. (2017) argued that model of fits indices can determine how well a hypothesis model fits the empirical data. Consequently, it can help to figure out the misspecification. Henseler et al. (2014) introduced the SRMR as a goodness of fit measure for PLS-SEM that can be used to avoid model misspecification. Therefore, this research used SRMR to identify the range of model misspecification (Henseler et al., 2014; Dijkstra \& Henseler, 2015). Considered a good fit if value less than 0.10 (Henseler et al., 2015). In present study, both SRMR values of saturated model and estimated model obtained are 0.08 and 0.10 respectively.

\section{Saturated Model}

SRMR

0.08
Estimated Model

0.10

\subsection{Structure Model}

When evaluate the structural model, Hair et al. (2017) proposed looking at the corresponding tvalues, Beta, and coefficient of determination $\left(R^{2}\right)$ through bootstrapping procedure with a resample of 5000. In addition, the basic measures, they also proposed researchers should report the predictive relevance $\left(\mathrm{Q}^{2}\right)$ and effect sizes $\left(\mathrm{f}^{2}\right)$. The results of the structural model of this research can be viewed in Table 1.6. First, we measure the significance and relevance of structural model relationships by using Smarts 3.3.2 to generate T-values for significance testing of the structural path. The results shown in Table 9, $\mathrm{H}_{1 a}, \mathrm{H}_{1 c}, \mathrm{H}_{1 \mathrm{~d}}, \mathrm{H}_{2 \mathrm{a}}, \mathrm{H}_{2 \mathrm{~b}}, \mathrm{H}_{5 a}, \mathrm{H}_{6}, \mathrm{H}_{7 a}$, and $\mathrm{H}_{7 b}$ (9 hypotheses) were found t-values more than 1.96 and level of significance was met and thus supported. In contrast, $\mathrm{H}_{1 \mathrm{~b}}, \mathrm{H}_{1 \mathrm{e}}, \mathrm{H}_{1 \mathrm{f}}, \mathrm{H}_{3}, \mathrm{H}_{4}$ and $\mathrm{H}_{5 \mathrm{~b}}(6$ hypotheses) with t-values less than 1.96 and were rejected.

Second, R2 is a measure predictive accuracy of the model. R2 values range from 0 to 1 with lager values representing higher levels of predictive accuracy. By referring to Table 1.6 , the $R^{2}$ value of for customers (0.287), MAKM (0.215), operations (0.373), results (0.659), strategy (0.392) and workforce (0.133) respectively. All $R^{2}$ value were above 0.13 as recommended by Cohen (1988) describing moderate (0.13) levels of predictive accuracy. However, operations, results and strategy construct met the moderate levels of predictive accuracy of 0.33 as proposed by Chin (1998). 
Table 9: Summarization of Result of Hypotheses Testing

$\begin{array}{cccccccccc}\begin{array}{c}\text { Hypothesi } \\ \mathbf{S}\end{array} & \text { Relationship } & \begin{array}{c}\text { Std } \\ \text { Beta }\end{array} & \begin{array}{c}\text { Std. } \\ \text { Error }\end{array} & \begin{array}{c}\text { t-value } \\ >1.96\end{array} & \text { Decision } & \mathbf{R}^{2} & \mathbf{f}^{2} & \mathbf{Q}^{2} & \mathbf{q}^{2} \\ \mathrm{H}_{1 \mathrm{a}} & \text { Leadership } \rightarrow \text { Strategy } & 0.626 & 0.062 & 10.167 & \text { Supported } & 0.392 & 0.645 & 0.377 & 0.605 \\ \mathrm{H}_{1 \mathrm{~b}} & \text { Leadership } \rightarrow \text { Customers } & 0.125 & 0.103 & 1.223 & \text { Rejected } & 0.287 & 0.013 & 0.248 & -0.019 \\ \mathrm{H}_{1 \mathrm{c}} & \text { Leadership } \rightarrow \text { MAKM } & 0.464 & 0.068 & 6.838 & \text { Supported } & 0.215 & 0.274 & 0.201 & 0.252 \\ \mathrm{H}_{1 \mathrm{~d}} & \text { Leadership } \rightarrow \text { Workforce } & 0.365 & 0.080 & 4.535 & \text { Supported } & 0.133 & 0.153 & 0.105 & 0.117 \\ \mathrm{H}_{1 \mathrm{a}} & \text { Leadership } \rightarrow \text { Operations } & 0.161 & 0.083 & 1.945 & \text { Rejected } & 0.373 & 0.034 & 0.328 & 0.015 \\ \mathrm{H}_{1 \mathrm{f}} & \text { Leadership } \rightarrow \text { Results } & 0.010 & 0.064 & 0.157 & \text { Rejected } & 0.659 & 0.001 & 0.589 & -0.010 \\ \mathrm{H}_{2 \mathrm{a}} & \text { Strategy } \rightarrow \text { Customers } & 0.448 & 0.097 & 4.637 & \text { Supported } & 0.287 & 0.171 & 0.248 & 0.372 \\ \mathrm{H}_{2 b} & \text { Strategy } \rightarrow \text { Results } & 0.289 & 0.085 & 3.386 & \text { Supported } & 0.659 & 0.088 & 0.589 & 0.061 \\ \mathrm{H}_{3} & \text { Customers } \rightarrow \text { Results } & 0.061 & 0.073 & 0.829 & \text { Rejected } & 0.659 & 0.007 & 0.589 & -0.015 \\ \mathrm{H}_{4} & \text { MAKM } \rightarrow \text { Results } & 0.120 & 0.082 & 1.461 & \text { Rejected } & 0.659 & 0.020 & 0.589 & -0.005 \\ \mathrm{H}_{5 \mathrm{a}} & \text { Workforce } \rightarrow \text { Operations } & 0.443 & 0.092 & 4.830 & \text { Supported } & 0.373 & 0.266 & 0.328 & -0.039 \\ \mathrm{H}_{5 b} & \text { Workforce } \rightarrow \text { Results } & 0.037 & 0.068 & 0.544 & \text { Rejected } & 0.659 & 0.002 & 0.589 & -0.039 \\ \mathrm{H}_{6} & \text { Operations } \rightarrow \text { Results } & 0.279 & 0.081 & 3.461 & \text { Supported } & 0.659 & 0.122 & 0.589 & 0.092 \\ \mathrm{H}_{7 a} & \text { LeanPractices } \rightarrow \text { Operations } & 0.201 & 0.079 & 2.545 & \text { Supported } & 0.373 & 0.058 & 0.328 & 0.051 \\ \mathrm{H}_{7 b} & \text { LeanPractices } \rightarrow \text { Results } & 0.269 & 0.063 & 4.251 & \text { Supported } & 0.659 & 0.171 & 0.589 & 0.134\end{array}$

Third, we evaluated effect sizes ( $f 2$ ) with referred to Cohen's (1988) guidelines, which are 0.02 , $0.15,0.35$ for small effects, medium effects, and large effects respectively. Table 1.6 shown the $f^{2}$ values of customers (0.007), leadership (0.001), strategy (0.010), MAKM $(0.002)$ and workforce $(0.002)$ have a small effect on producing $R^{2}$ for results. Then follow by operations $(0.123)$ and Lean practiced (0.171) have a medium effect on producing $R^{2}$ for results. Next is leadership (0.013) and strategy (0.171) have a small and medium effect respectively on producing $R^{2}$ for customers. The $f^{2}$ values found in Table 1.6 also shown that leadership (0.274) has medium effect on producing $R^{2}$ for MAKM but leadership (0.645) has a large effect on strategy. Follow by the results of leadership (0.153) have a medium effect on workforce, however leadership (0.034) have a small effect on producing $R^{2}$ for operations. We also see the interaction term's $f^{2}$ effect size have a value of 0.266 and 0.058 for workforce and Lean practices respectively indicated that have a medium and small effect on producing $\mathrm{R}^{2}$ for operations.

Lastly, the Q2 value is generated by using the blindfolding procedure for a specified omission distance D (Hair et al., 2017). In this case, the sample size is 150 . Thus, omission distance values of 5 , 6 and 10 were not chosen because that would have resulted in integer values. The omission distance value of 7 was used to run this blindfolding analysis. The results show that all $Q^{2}$ values for customers (0.248), MAKM (0.201), operations (0.328), results (0.589), strategy (0.377) and workforce (0.105) were greater than 0 , denoting that the model had adequate predictive relevance.

\section{Discussion and Implications}

\subsection{Discussion}

A quick revisit to the research objectives shows that this research was primarily undertaken to deliver responses to five research questions, which included: (1) What is the effect on leadership towards strategy, customers, MAKM, workforce, operations and performance? (2) What is the effect on strategy towards customers and performance? (3) What is the effect of workplace towards operations and performance? (4) What is the effect of customers, MAKM and operations towards performance? (5) What is the effect of Lean practices towards performance? Do the Lean practices will give better influence on operations? In answering the research questions, empirical study was conducted. The research proposed here reflects the empirical results showing the relationships 
between leadership, Lean practices and BE. In second order structure model analysis, this research found that 9 out of 15 hypotheses were supported and statistically significant. The remaining 6 hypotheses were rejected.

In structure analysis, $\mathrm{H}_{1 \mathrm{a}} \mathrm{H}_{1 \mathrm{c}}$ and $\mathrm{H}_{1 \mathrm{~d}}$ were supported confirming that leadership of Baldrige excellence framework is a key influence on strategy, MAKM and workforce in E\&E organization. Based on direct influence ( $t$-value), the most influential constructs by E\&E manufacturing companies' leadership are strategy (10.167), MAKM (6.838) and workforce (4.535). While the present finding is supported to the hypothesized positive relationship, it is strongly aligned with the findings in Matondang, et al. (2018) in which they found leadership influenced the strategy, MAKM, and workforce in palm oil factory in Indonesia with similar Baldrige excellence framework criteria used. This study also supports Brown (2013) research on BE in Australia companies which concluded that leadership communicating strategy and drive employee's engagement are primary tasks. Our results of leadership influenced MAKM may explained by the fact that many top-level managers are willing to provide support on new knowledge and technology of value-chain to their staff in manufacturing organizations (Aziati, et al., 2017). Our findings also support Oakland and Tanner (2008) assertion that Leadership Excellence does have a positive influence on employee outcomes in both private and public sector organisations.

In contrast, the $\mathrm{H}_{1 \mathrm{~b}}$ ( $\mathrm{t}$-value 1.223) was not supported that revealing leadership is not influence the customers of E\&E companies. Our study has obtained consistent results of research by Matondang, et al. (2018) found leadership has no effect on customers using Baldrige model criteria. Present study findings on leadership influence on operations $\left(\mathrm{H}_{1 \mathrm{e}}, \mathrm{t}\right.$-value 1.945) has similar findings with Misron et al. (2017)'s study in Malaysia halal certified food manufacturer which concluded that leadership has no positive impact on operations. This means that the senior managers of E\&E may indirectly participate in operations and the direct involvement in daily operations only involve by middle-level and low-lower management teams. Furthermore, $\mathrm{H}_{1 \mathrm{f}}$ (t-value 0.157 ) was not supported and found positively insignificant between leadership and results. This finding concluded in the present study appears to be constant with other studies that look into similar issues of firm performance. Past studies have suggested the important of leadership leading firm's performance, but empirical evidence has also revealed that many organizations are not getting their predictable results from the leaders. Choi and Behling (1997) tried to clarify why certain BE initiatives ended up with disappointments. By observing attitudes of managers who have positive inclinations toward customers, time, and market seem to have more proactive types of quality initiatives, which therefore affect performance of their company.

The strategy consists of development and implementation is positively related to customers (t-value 4.637) and performance (t-value 3.386) of the E\&E company. Hence, the $\mathrm{H}_{2 a}$ and $\mathrm{H}_{2 b}$ were supported. Our results support past study by Muogboh and Salam (2009) confirmed that the existence of a relationship between manufacturing strategy and manufacturing firm performance. Our finding further supported by Matondang, et al. (2018) also found strategy has influence performance of of palm oil factory engaged in the palm oil industry.

Even through the relationship between customers and MAKM, which is $\mathrm{H}_{3}$ (t-value 0.829) and $\mathrm{H}_{4}$ (t-value 1.461) were found positively insignificant with results, the finding concluded in the present study looks to be consistent with other studies that focused similar issues of business performance. Past studies in BE have supported customers and MAKM have no causal positive effect on performance of the company (Masrom et. al., 2017). MAKM does not have a direct influence on the results, consistent with the findings of Peng and Prybutok (2015) in the municipal government of Texas. The results may indicate that MAKM plays a supporting role in overall system of E\&E companies and not a direct driver of results.

The findings present study indicating $B E$ dimension, workforce is influence operations but not the outcomes of the E\&E company. The $\mathrm{H}_{5 \mathrm{a}}$ and $\mathrm{H}_{5 b}$ with $\mathrm{t}$-values of 4.830 (supported) and 0.544 (rejected) respectively. Our result also confirms the findings of previous studies in this area, such as Fok-Yew and 
Ahmad (2014), Jurburg et al. (2017), Peng and Prybutok (2015), and Matondang et al. (2018) about the workforce engagement of achieving successful operations improvement and performance. Hence, workforce has a substantial influence on operations in Malaysia E\&E companies. In PLS-SEM analysis, $\mathrm{H}_{5 b}$ was not supported illustrating that workforce in Baldrige excellence framework is not a key factor to achieve BE. This finding is consistent with workforce has no causal positive influence on operational performance in BE study in Malaysia context (Misron et. al., 2017). However, workforce has causal positive effect on operation focus in similar study. This indicates that workforce itself cannot improve overall performance of E\&E companies. For example, workforce engaging to operations then will give better results confine in typical operational performance like quality, speed/time, cost and flexibility (Voss, 1995a; Kuruppuarachchi \& Perera, 2010).

While the current finding is support to the hypothesized positive relationship, it is firmly aligned with the findings in Matondang, et al. (2018) and Peng and Prybutok (2015) in which they found operations have significant direct relationship on performance of company. The $\mathrm{H}_{6}$ with $\mathrm{t}$-value of 3.461 is supported. For example, argument can be made with the operations practices and the production system design have significant positive influence on the performance factors of the manufacturing plants (Taj \& Morosan, 2011). Our results further ascertain the positive relationship between operations and performance of E\&E manufacturing companies.

The result of PLS-SEM analysis show the Lean practices has a positive and statistically significant relationship with operations. Therefore, $\mathrm{H}_{7 a}$ with $\mathrm{t}$-value of 2.545 is fully supported. This finding strengthened those of previous researches such as Taj and Morosini (2011) who found that Lean factors are strongly related to operations practice and production system design. Our result also supported empirical study findings that Lean practice have increased the efficiency of production processes and enhanced quality towards achieving firms' target gaols (Ahmad, Redaheb \& Zabric, 2016). This finding aligned with the fact that if an E\&E organization given more attention of Lean tools into operations, they will benefit on better results on work processes and operational effectiveness. Hypothesis, $\mathrm{H}_{7 \mathrm{~b}}$ proposed that Lean practices would leads to the better results of BE. The results gathered from the empirical data analysis with $\mathrm{t}$-value of 4.251 show that Lean practices positively and significantly affects BE. This finding is theoretically consistent with others that have empirically shown that Lean practices for achieving excellence performance (Nawanir, et al., 2018, Bento, 2018; Wickramasinghe \& Wickramasinghe, 2017; Alsmadi et al., 2012; Shah \& Ward, 2007). The result also supported the view of Taj and Morosan (2011) who have confirmed that a positive influence of Lean operations on the achievement of the Chinese manufacturing sector. In overall, Lean practices which focus on waste reduction will giving better results.

Based on the suggested research framework, present research is predicted to deliver numerous contributions to methodology, theory and practice.

\subsection{Theoretical Implications}

As for theoretical perspective, it proposed an integrated model to confirm the Lean practices, leadership and BE have relationship. This study is among the first to address such model in the context of emerging developing countries. It also reflects an extending BE paradigm especially with the knowledge on the understanding of Lean practices, leadership and BE. Therefore, it adds value to the knowledge of BE domain.

\subsection{Methodology Implications}

In addition to the conventional performance metrics (economic measure), this study add-on noneconomic measure of latest Baldrige excellence framework in a composite performance index. This methodology contribution may be useful for other studies on the initiatives deployment to predict business performance. Therefore, it contributes to the methodology perspective. 


\subsection{Managerial Implications}

The study finds few statistically significant relationships with practical implementations. E\&E manufacturing organizations that are interested in pursuing BE must be concerned with BE elements as well as with Lean practices in an organization. Management teams and employees play imperative role that would ensure Baldrige excellence framework is able to bring best outcomes for organizations and for the people in them. This study also desires to address a new insight of the framework so that Malaysia Productivity Corporation (MPC) can distinguish the appropriate model of BE based on organization needs. Conversely, E\&E companies may pay attention on four elements (leadership, customers, MAKM and workforce) which are not significantly related to the BE. They can reach excellence level once they manage to close those gaps.

\subsection{Limitations and Future Research Suggestions}

The present study is confined to E\&E industry. The future research topic may focus on focus on a new era of industrialization like Industry 4.0 firms those are the ones that extensively adopt automation and other digital technologies for higher productivity, cost reduction, pursue growth and operational excellence. It is obviously leadership is a key element or driver for BE achievement and its influence will be the topic of future research to regulate what are the leadership styles or traits more favourable to achieve $\mathrm{BE}$. Future progression of the $\mathrm{BE}$ research field also can investigate the other BEM such as Deming Prize, EFQM or MBF in Malaysia context. Hopefully it will be able to deliver a new perception on how organization react to those models and also enhance the business performance.

\section{References}

Adebanjo, D. (2001). TQM and business excellence: is there really a conflict? Measuring Business Excellence, 5(3), 37-40.

Adebanjo, D. \& Mann, R. (2008). Business Excellence. BPIR Management Brief. Palmerston North, New Zealand: BPIR.

Afthonidis, E. and Tsiotras, G. (2014). Strategies for business excellence under an economic crisis. The TQM Journal, 26(6), 610-624.

Ahmad, M. M. and Elhuni, R. (2014). Critical quality factors for successful TQM implementation in Libyan oil and gas sector. Benchmarking: An International Journal, 21(5), 713-733.

Ahmad, K., Redaheb, N. N. M and Zabric, S. M. (2016). Proceedings of the 28th International Business Information Management Association Conference, 9-10 November 2016. Vision 2020: Innovation Management, Development Sustainability, and Competitive Economic Growth. Retrieved from https://www.researchgate.net/publication/311716176

Aladwan, S.A. and Forrester, P. (2016). The leadership criterion: Challenges in pursuing excellence in the Jordanian public sector. The TQM Journal, 28(2), 295-316.

Albliwi, S., Antony, J., Lim, S. A. H. and van der Wiele, T. (2014). Critical failure factors of Lean Six Sigma: a systematic literature review. International Journal of Quality \& Reliability Management, 31(9), 1012-1030.

Alsmadi, M, Almani, A. \& Jerisat, R. (2012). A comparative analysis of Lean practices and performance in the UK manufacturing and service sector firms. Total Quality Management, 23(4), 381-396.

Antony, Arulraj \& Umamaheswari (2018). Through Employee Engagement - A Critical Analysis on the Driving Factors of Employee Engagement. International Journal of Mechanical and Production. Engineering Research and Development (IJMPERD). 8(2), Apr 2018, 1271-1282.

Aziati, A. H. N., Ling, Y. M., Ahmad, M., M. F. \& Abdullah, N. H. (2017). The Influence of Information Technology and Operational Competencies toward Supply Chain Agility: Findings from Textile Manufacturer. International PostGraduate Conference on Applied Science \& Physics 2017. IOP Conf. Series: Journal of Physics: Conf. Series 1049 (2018) 012011, doi:10.1088/17426596/1049/1/012011.

Babbie, E. R. (2005). The Basics of Social Research. Thomson Wadsworth. 
Bagozzi, R. P., \& Yi, Y. (1988). On the evaluation of structural equation models. Journal of the Academy of Marketing Science, 16(1), 74-94.

Bakotic, D. \& Rogosic, A. (2017). Employee involvement as a key determinant of core quality management practices. Total Quality Management \& Business Excellence, 28:11-12, 1209-1226, DOI: 10.1080/14783363.2015.1094369.

Bento, G.D.S., Tontini G.\& Tontini, G. (2018). Developing an instrument to measure lean manufacturing maturity and its relationship with operational performance. Total Quality Management \& Business Excellence, 1(19).

BPIR. (2020). Business Performance Improvement Resource. https://www.bpir.com/businessexcellence-bpir.com.html (Accessed on July 30, 2020).

Brown, A. (2013). Managing challenges in sustaining business excellence,' International Journal of Quality \& Reliability Management, 30(4), 46-475.

Brumme, H., Simonovich, D., Skinner, W., \& Van Wassenhove, L. (2015). The strategy-focused factory in turbulent times. Production and Operations Management, 24(10), 1513-1523.

Chavez, R., Gimenez, C., Fynes, B., Wiengarten, F. and Yu, W. (2013). Internal lean practices and operational performance: The contingency perspective of industry clockspeed. International Journal of Operations \& Production Management, 33(5), 562-588.

Choi, T. Y \& Behling, O. C. (1997). The TQM Paradox: Relations among TQM practices, plant performance, and customer satisfaction. Academy of Management Executive, 11(1), 37-47.

Cohen, J. (1988). Statistical power analysis for the behavioral sciences. Mahwah, NJ: Lawrence Erlbaum.

DOSM. (2019). Department of Statistics Malaysia. Retrieved from https://www.dosm.gov.my/v1/

EFQM. (European Foundation for Quality Management) (1999). The Excellence Model, EFQM, Brussels.

Ferdowsian, M. C. (2016). Total business excellence - a new management model for operationalizing excellence. International Journal of Quality \& Reliability Management, 33(7), 942-984.

FMM. (2018). FMM-MATRADE industry directory electrical and electronics Malaysia 2017/18, Kuala Lumpur: Federal of Malaysian Manufacturers (FMM).

Fornell, C. \& Larcker, D.F. (1981). Evaluating structural equation models with unobservable variables and measurement error. Journal of Marketing Research, 18 (1), 39-50.

Found, P. Lahy, A. \& Williams, S., Hu, Q. \& Mason, R. (2018). Towards a theory of operational excellence, Total Quality Management \& Business Excellence, 29:9-10, 1012-1024. Retrieved from https://doi.org/10.1080/14783363.2018.1486544

Fok-Yew, O. \& Ahmad, H. (2014). The Effect of Change Management on Operational Excellence in Electrical and Electronics Industry: Evidence from Malaysia. British Journal of Economics, Management \& Trade, 4(8), 1285-1305.

Furlan, A., Vinelli, A. and Dal Pont, G. (2011). Complementarity and lean manufacturing bundles: An empirical analysis. International Journal of Operations \& Production Management, 31(8), 835-850.

Ghobakhloo, M. and Azar, A. (2018). Business excellence via advanced manufacturing technology and lean-agile manufacturing. Journal of Manufacturing Technology Management, 29(1), 2-24.

Gloet, M. \& Samson, D. (2017). Linking Knowledge Management, Business Excellence and Innovation Performance. Proceedings of the 50th Hawaii International Conference on System Sciences. Retrieved from http://hdl.handle.net/10125/41713

Gorenak, S. (2015). European Foundation for Quality Management Excellence Model can encourage ISO 26000 implementation. In V Bobek (ed). Perspectives on business and management. London, England: IntechOpen Limited. Retrieved from https://doi.org/10.5772/60959

Gosselin, M. (2005). An empirical study of performance measurement in manufacturing firms,' International Journal of Productivity and Performance Management, 54(5/6), 419-437.

Henseler, J., Dijkstra, T. K., Sarstedt, M., Ringle, C. M., Diamantopoulos, A., Straub, D. W., et al. (2014). Common beliefs and reality about partial least squares: Comments on Rönkkö \& Evermann (2013). Organizational Research Methods, 17, 182-209. 
Henseler, J., Ringle, C. M., \& Sarstedt, M. (2015). A new criterion for assessing discriminant validity in variance-based structural equation modelling. Journal of the Academy of Marketing Science, 43, $115-135$.

Hermel, P. (1997). The new faces of total quality in Europe and the US. Total Quality Management, 8(4), 131-43.

House, R. J., Javidan, M. and Dorfman, P. (2001). Project globe: An introduction,' Applied Psychology, 50, 489-505.

Hulland, J. (1999). Use of partial least squares (PLS) in strategic management research: a review of four recent studies. Strategic Management Journal, 20(2), 195-204.

Javidan, M. and Dastmalchian, A., (2009). Managerial implications of the GLOBE Project: A study of 62 societies. Asia Pacific Journal of Human Resources, 47(1), 41-58.

Jurburg, D., Viles, E., Tanco, M., \& Mateo, R. (2017). What motivates employees to participate in continuous improvement activities? Total Quality Management \& Business Excellence, 28(13), $1469-1488$.

Juran, J. M. (1986). Quality trilogy. Quality Progress, August, 12-24.

Hair, J. F., Ringle, C. M., \& Sarstedt, M. (2012). Partial least squares: The better approach to structural equation modelling? Long Range Planning, 45(5-6), 312-319.

Hair, J. F., Jr., Hult, G. T. M., Ringle, C. M., \& Sarstedt, M. (2013). A Primer on Partial Least Squares Structural Equation Modeling (PLS-SEM). Thousand Oaks: Sage.

Hair, J. F., Jr., Hult, G. T. M., Ringle, C. M., \& Sarstedt, M. (2017). A Primer on Partial Least Squares Structural Equation Modeling. 2nd Ed. Thousand Oaks: Sage.

Kanji, G. K. (2001). Measuring Business Excellence, London/New York: Routledge.

Kanji, G. K. (2002). Measuring Business Excellence, London/New York: Routledge.

Kline, R. B. (2011). Principles and practice of structural equation modelling. New York: Guilford Press.

Krejcie, R. V., \& Morgan, D. W. (1970). Determining Sample Size For Research Activities. Educational and Psychological Measurement, 30, 607-610.

Krumwiede, K.R. and Charles, S.L. (2006). Finding the right mix. How to match strategy and management practices to enhance firm performance. Strategic Finance, 87, 37-43.

Kuruppuarachchi, D. and Perera, H. S. C. (2010). Impact of TQM and Technology Management on Operations Performance. The IUP Journal of Operations Management, 13(3), 23-47.

Laureani, A. and Antony, J. (2017). Leadership Characteristics for Lean Six Sigma,' Total Quality Management \& Business Excellence, 28(4), 405-426.

Laureani, A., \& Antony, J. (2019). Leadership and Lean Six Sigma: a systematic literature review, Total Quality Management \& Business Excellence, 30:1-2, 53-81.

Liu, S., Leat, M., Moizer, J., Megicks, P. and Kasturiratne, D. (2013). A decision-focused knowledge management framework to support collaborative decision making for lean supply chain management,' International Journal of Production Research, 51(7), 2123-2137.

Lu, D., Betts, A. and Croom, S. (2011). Re-investigating business excellence: Values, measures and framework,' Total Quality Management \& Business Excellence, 22(12), 1263-1276.

MPC (2019). Malaysia Productivity Corporation. Retrieved from http://www.mpc.gov.my/malaysiabusiness-excellence-framework/

Matondang, Alda, and Nasution (2018). Model development based on baldrige excellence framework criteria in palm oil factory. SEMIRATA- International Conference on Science and Technology 2018, IOP Conf. Series: Journal of Physics: Conf. Series 1116 (2018) 022025.

Masrom, N. R., Rasa, R. Z. R. M. and Daut, B. A. T. (2017). The Impact of Business Excellence on Operational Performance among Halal Certified Food Manufacturers in Malaysia. MATEC Web of Conferences, 135, 00041 (2017).

Matthews, R. A., Maura, J. M., Rachel, C. T. and English, L. (2014). Family-Supportive Supervisor Behaviors, Work Engagement, and Subjective Well-Being: A Contextually Dependent Mediated Process. Journal of Occupational Health Psychology, 19(2), 168-181.

McDonald, I., Zairi, M. and Idris, M.A. (2002). Sustaining and transferring excellence. Measuring Business Excellence, 6 (2), 20-30. 
McShane, S. L. and Von Glinow, M. A. (2008). Organizational behavior (4th ed., p. 402s), New York, NY: McGraw-Hill.

Metaxas, I. N. and Koulouriotis, D. E. (2017). Business excellence measurement: a literature analysis (1990-2016). Total Quality Management \& Business Excellence. [Online], [Retrieved December 23, 2018], DOI: 10.1080/14783363.2017.1356201

Miner, J. B. (2005). Organizational Behavior 1: Essential Theories of Motivation and Leadership. M.E. Sharpe, Armonk, New York.

Muogboh, O. S. and Salami, A. (2009). A New Perspective on the Manufacturing Strategy: Performance Relationship. International Journal of Business Research, 9(3), 114-126.

National Quality Institute (2007). Canada Awards for Excellence. [Online], [Retrieved October 22, 2018], www.nqi.ca/caeawards/

Nawanir, G., Lim, K. T., Othman, S. N. and Adeleke, A. Q. (2018). Developing and Validating Lean Manufacturing Constructs: An SEM Approach. Benchmarking: An International Journal, [Online], [Retrieved October 10, 2018] https://doi.org/10.1108/BIJ-02-2017-0029

NIST. (2019). National Institute of Standards and Technology. Baldrige Excellence Framework 20192020 - Business/Non-profit/Government, NIST.

Oakland, J. S. and Tanner, S. J. (2008). The relationship between Business Excellence and Performance - An empirical study using Kanji's Leadership Excellence Model,' Total Quality Management, 19(78), 733-749.

Ohno, T. (1978). Toyota Production System. Beyond Large-Scale Production; Productivity Press: Portland, OR, USA.

Peng, X \& Paybook, V. (2015). Relative effectiveness of the Malcolm Baldrige National Quality Award categories. International Journal of Production Research, 53(2), 629-647, DOI: 10.1080/00207543.2014.961207

Pettersen, J. (2009). Defining lean production: some conceptual and practical issues. TQM Journal, 21(2), 127-142.

Prabowo, D. I., One, A., Onhanger, J., Brown, S., and Brown, S. (2016). Supply chain processes: Linking supply logistics integration, supply performance, lean processes and competitive performance. International Journal of Operations \& Production Management, 36(2), 220-238.

Price, O. M., Pepper, M. \& Stewart, M. (2018). Lean six sigma and the Australian business excellence framework: An exploratory case within local government. International Journal of Lean Six Sigma, 1-14.

Rao, M. (2016). Debunking myths about soft leadership and exploring it to achieve organizational excellence and effectiveness. Industrial and Commercial Training, 48(7), 362-366.

Rasa, R. Z. R., Raiman, U. S., and Ahmad, M. F. B. (2015). Relationship between lean production and operational performance in the manufacturing industry. Paper presented at the IOP Conference Series: Materials Science and Engineering, 3-6 August 2015, Macau, China.

Sahoo, S. and Yadav, S. (2018). Lean implementation in small- and medium-sized enterprises: An empirical study of Indian manufacturing firms. Benchmarking: An International Journal, 25(4), 11211147.

Saami, G. A, Abu-Taye, B. A., Yosef, F., Manta, M. and Al-Matane, M. I. (2018). Relation between Total Quality Management Practices and Business Excellence: Evidence from Private Service Firms in Jordan. International Review of Management and Marketing, 8(1), 28-35.

Samuelsson, P. \& Nilsson, L. E. (2002). Self-assessment practices in large organizations: Experiences from using the EFQM excellence model. International Journal of Quality \& Reliability Management, 19(1), 10-23. Retrieved from https://doi.org/10.1108/02656710210413426

Seen, B., Parasailer. I. S. and Bryozoan, G. (2012). Proposition of a model for measuring adherence to lean practices: applied to Turkish automotive part suppliers. International Journal of Production Research, 50(14), 3878-3894.

Shafiq, M., Laredo, F. \& Hafeez, K. (2017). The effect of TQM on organisational performance: empirical evidence from the textile sector of a developing country using SEM. Total Quality Management \& Business Excellence, DOI:10.1080/14783363.2017.1283211. 
Shah, R. \& Ward, P.T. (2007). Defining and developing measures of lean production. Journal of Operations Management, 25 (4), 785-805.

Sharma, M. and Kodaly, R. (2008). Development of a framework for manufacturing excellence,' Measuring Business Excellence. 12(4), 50-66.

Symbolic, A., Taddeo, R. and Morganite, A. (2014). Value and Wastes in Manufacturing. An Overview and a New Perspective Based on Eco-Efficiency, Administrative Sciences, 4, 173-191.

Singh, T. P. and Chauhan, G. (2013). Significant Parameters of Labour Flexibility Contributing to Lean Manufacturing. Global Journal of Flexible Systems Management, 14(2), 93-105.

Slack, N., Brandon-Jones, A. and Johnston, R. (2013). Operations Management, Essex, UK, Prentice Hall.

Sony, M. (2019). Implementing sustainable operational excellence in organizations: an integrative viewpoint. Production \& Manufacturing Research, DOI:10.1080/21693277.2019.1581674 (Accessed 2 April 2019).

Sridharan, V. R., Gopi Kumar V, Nair, S., Chakraborty, A. and Antony, J. (2017). Assessment of Critical Failure Factors (CFFs) of Lean Six Sigma in real life scenario: evidence from manufacturing and service industries. Benchmarking: An International Journal. [Online], [Retrieved January 12, 2019], https://doi.org/10.1108/BIJ-10-2017-0281

Stoughton, R., \& Johnston, R. (2005). Operational performance gaps in business relationship. International Journal of Operations \& Production Management, 25(4), 320-332.

Taj, S. \& Morosini, C. (2011). The impact of lean operations on the Chinese manufacturing performance. Journal of Manufacturing Technology Management, 22(2), 223-240.

Thomas, A. J., Francis, M., Fisher, R. and Byard, P. (2016). Implementing Lean Six Sigma to overcome the production challenges in an aerospace company. Production Planning \& Control, 27(78), 591603.

Union of Japanese Scientists and Engineers (2010). The Deming Prize. [Online]. [Retrieve October 28, 2018], www.juse.or.jp/e/ deeming/index.html

van Assen, M. F. (2018). Lean, process improvement and customer focused performance. The moderating effect of perceived organisational context. Total Quality Management \& Business Excellence. [Online] [Retrieved October 21, 2018], https://doi.org/10.1080/14783363.2018.1530591

Kartika, L. and Kanaloa, M. (2017). The Business Excellence assessment. TRANSCOM 2017: International scientific conference on sustainable, modern and safe transport. Procedia Engineering, 192, 917-922.

Vinod, S. and Joy, D. (2012). Structural Equation Modelling of lean manufacturing practices. International Journal of Production Research, 50(6), 1598-1607.

Vora, M. K. (2013). Business excellence through sustainable change management. The TQM Journal, 25 (6), 625-640.

Voss, C.A. (1995a). Alternative paradigms for manufacturing strategy. International Journal of Operations \& Production Management, 15(4), 5-16.

Wahab, M. H. A. A, Ismail, M. and Muhyiddin, M. N. (2016). Factors Influencing the Operational Excellence of Small and Medium Enterprise in Malaysia. International Journal of Academic Research in Business and Social Sciences, 6 (12).

Wickremasinghe, G.L.D., Wickremasinghe, V. (2017). Implementation of lean production practices and manufacturing performance: The role of lean duration. Journal of Manufacturing Technology Management, 28(4), 531-550. Retrieved from https://doi.org/10.1108/JMTM-08-2016-0112

Winifred, Al. (2016). Malaysia facing biggest economic challenge. [Online]. [Retrieved June 25, 2016], http://themalaysianreserve.com/new/story/malaysia-\%E2\%80\%98facing-biggest-economicchallenge\%E2\%80\%99

Womack, J.P., Jones, D.T. and Roost, D. (1991). The Machine That Changed the World, Lean Enterprise Institute, Cambridge, MA.

Wong, K. K. (2013). Partial least square structural equation modelling (PLS-SEM) techniques using Smarts. Marketing Bulletin, 2013, 24, Technical Note. 
Yukl, G. A. (2006). Leadership in organizations (6th ed., ch.3). Upper Saddle River, NJ: Pearson Education.

Drilid, I. and Dulcie, Z. (2016). Business Excellence as a Success Factor for the Performance of Large Creation Enterprises. Management, 21(1), 145-162.

Sot, C., Amit, R. (2008). The fit between product market strategy and business model: Implications for firm performance. Strategic Management Journal, 29(1), 1-26. 